\title{
PRZYPOWIEŚĆ O TALENTACH
}

\section{Ewangelia według św. Mateusza 25: 14-30 \\ Biblia Tysiąclecia \\ Wydawnictwo Pallotinum, Poznań 2003}

14 Podobnie też [jest] jak z pewnym człowiekiem, który mając się udać w podróż, przywołał swoje sługi i przekazał im swój majątek.

15 Jednemu dał pięć talentów, drugiemu dwa, trzeciemu jeden, każdemu według jego zdolności, i odjechał. Zaraz

16 ten, który otrzymał pięć talentów, poszedł, puścił je w obrót i zyskał drugie pięć.

17 Tak samo i ten, który dwa otrzymał; on również zyskał drugie dwa.

18 Ten zaś, który otrzymał jeden, poszedł i rozkopawszy ziemię, ukrył pieniądze swego pana.

19 Po dłuższym czasie powrócił pan owych sług i zaczął rozliczać się z nimi.

20 Wówczas przyszedł ten, który otrzymał pięć talentów. Przyniósł drugie pięć i rzekł: „Panie, przekazałeś mi pięć talentów, oto drugie pięć talentów zyskałem”.

21 Rzekł mu pan: „Dobrze, sługo dobry i wierny! Byłeś wierny w rzeczach niewielu, nad wieloma cię postawię: wejdź do radości twego pana!"

22 Przyszedł również i ten, który otrzymał dwa talenty, mówiąc: „Panie, przekazałeś mi dwa talenty, oto drugie dwa talenty zyskałem".

23 Rzekł mu pan: „Dobrze, sługo dobry i wierny! Byłeś wierny w rzeczach niewielu, nad wieloma cię postawię: wejdź do radości twego pana!"

24 Przyszedł i ten, który otrzymał jeden talent, i rzekł: „Panie, wiedziałem, żeś jest człowiek twardy: chcesz żąć tam, gdzie nie posiałeś, i zbierać tam, gdzieś nie rozsypał. Bojąc się więc, poszedłem i ukryłem twój talent w ziemi. Oto masz swoją własność!" Odrzekł mu pan jego: „Sługo zły i gnuśny! Wiedziałeś, że chcę żąć tam, gdzie nie posiałem, i zbierać tam, gdziem nie rozsypał.

27 Powinieneś więc był oddać moje pieniądze bankierom, a ja po powrocie byłbym z zyskiem odebrał swoją własność.

Dlatego odbierzcie mu ten talent, a dajcie temu, który ma dziesięć talentów.

Każdemu bowiem, kto ma, będzie dodane, tak że nadmiar mieć będzie. Temu zaś, kto nie ma, zabiorą nawet to, co ma.

30 A sługę nieużytecznego wyrzućcie na zewnątrz - w ciemności! Tam będzie płacz i zgrzytanie zębów". 


\section{KOMENTARZ}

\section{Grzegorz Lissowski \\ Uniwersytet Warszawski}

\section{Alokacja zasobów - efekt św. Mateusza}

\section{DECYZJE INWESTYCYJNE}

Przytoczona „Przypowieść o talentach” może stanowić podstawę szeregu komentarzy. Ograniczę się jedynie do trzech kwestii. Pierwsza dotyczy sposobu podziału majątku z intencją jego pomnożenia. Wyjeżdżający w podróż pan rozdzielił swój majątek między trzech sług: „Jednemu dał pięć talentów, drugiemu dwa, trzeciemu jeden, każdemu według jego zdolności, i odjechał”. Warto przypomnieć, że talent oznaczał wielkiej wartości monetę, która w owym czasie była w użyciu, a w sensie przenośnym - zdolności, w które wyposażony jest człowiek.. W tym wypadku są to zdolności do pomnażania dóbr. Zdolności te określają szanse na zwiększenie wielkości dóbr, ale nie gwarantują sukcesu. Rozdział dóbr jest więc decyzją inwestycyjną w sytuacji niepewności.

Podstawą podejmowania decyzji inwestycyjnych w sytuacji niepewności są dwa główne kryteria: efektywność, czyli maksymalizacja korzyści, i ryzyko, czyli minimalizacja strat (por. Tyszka, 2010: 308-311). Systematyczne badania nad sposobami podejmowania decyzji inwestycyjnych rozpoczęły się od opublikowania artykułu Henry'ego Markowitza (1952). Markowitz zauważył, że aby uzyskać możliwie wysoki średni stopień zwrotu z inwestycji, a zarazem zmniejszyć poziom ryzyka (mierzony odchyleniem standardowym stopy zwrotu z inwestycji), należy stosować metodę dywersyfikacji, czyli odpowiednio rozdzielać fundusze między możliwe inwestycje (tj. wybierać efektywny portfel akcji). Istnieje jednak wiele takich efektywnych portfeli, które przy danej średniej stopie zwrotu stwarzają najmniejsze ryzyko, a zarazem przy danym ryzyku zapewniają największą średnią stopę zwrotu. Ograniczeniem koncepcji Markowitza jest konieczność posiadania pełnej informacji o stopach zwrotu możliwych inwestycji oraz o związanych z nimi odchyleniach standardowych (zależnych w istotny sposób od założeń o rozkładach stopy zwrotu). Przegląd najczęściej stosowanych obecnie miar oceny stopnia dywersyfikacji portfeli inwestycyjnych, nie tylko związanych z propozycją Markowitza, przedstawiła m.in. Agata Gluzicka (2017).

Znacznie mniejsze wymagania informacyjne ma podejście związane z entropią. Pierwszymi badaczami, którzy zastosowali entropię do wyboru portfeli inwestycyj- 
nych, byli Georges C. Philippatos i Charles J. Wilson (1972). Podejście to wymaga znajomości oceny prawdopodobieństw sukcesów poszczególnych inwestycji i ewentualnie powiązań między nimi. Minimalne oczekiwane ryzyko związane z inwestycjami zapewnia wybór odpowiednich inwestycji i podział funduszy między nie proporcjonalnie do oceny prawdopodobieństw ich sukcesów. Inaczej mówiąc, w wyborze portfela inwestycyjnego chodzi o to, aby entropia portfela była jak największa. ${ }^{1}$ Przegląd zastosowań entropii do ekonomicznej analizy finansów, a w szczególności do wyboru portfeli inwestycyjnych, przedstawili Rongxi Zhou, Ru Cai i Guanqun Tong (2013).

Zakładając, że oceny zdolności sług do pomnażania dobra były właściwymi ocenami prawdopodobieństw osiągnięcia przez nich sukcesów, sposób rozdziału talentów między nich powinien zapewniać minimalizację ryzyka i maksymalizację oczekiwanej stopy zwrotu. Rezultaty ich działań generalnie to potwierdziły.

Można podać szereg przykładów, w których proporcjonalny do prawdopodobieństw sposób podziału zapewnia uzyskanie optymalnych rozwiązań. Intersująca jest seria eksperymentów psychologicznych, w których badano średni czas reakcji badanych na zapalanie się lampek. Okazało się, że zależał on od częstości zapalania się tych lampek. Na częściej zapalające się lampki badani reagowali szybciej, a średni czas reakcji był liniową funkcją entropii częstości zapalania się lampek (por. Jagłom i Jagłom, 1963: 69-72). W teorii kodowania dowodzi się, że optymalny system kodowania (np. za pomocą ciągu sygnałów kropka i kreska jak w alfabecie Morse’a) powinien mieć średnią długość sygnałów kodu dla zapisania wiadomości możliwie najmniejszą i zbliżoną do entropii wiadomości elementarnych, np. liter (Abramson, 1969). W systemach identyfikacji obiektów za pomocą serii pytań (podobnie jak w grze „Inteligencja”) średnia liczba zadawanych pytań powinna być najbliższa entropii zbioru obiektów.

\section{NARASTAJĄCE NIERóWNOŚCI EKONOMICZNE}

„Przypowieść o talentach” kończy się podziałem nagród i kar oraz znamiennym i często powtarzanym zdaniem: „Każdemu bowiem, kto ma, będzie dodane, tak że nadmiar mieć będzie. Temu zaś, kto nie ma, zabiorą nawet to, co ma”. Podobne sformułowanie występuje również w innych miejscach w Ewangelii według św. Mateusza (np. 12:13), a także w innych ewangeliach. „Przypowieść o minach” w Ewangelii według św. Łukasza (19:11-27) kończy się stwierdzeniem „każdemu, kto ma, będzie

$\overline{1}$ Niech $p_{1}, p_{2}, \ldots, p n$-- oznacza dowolne $n$ dodatnich liczb sumujących się do 1 , a $q_{1}, q_{2}, \ldots, q_{n}$ - oznacza jakiekolwiek inne $n$ dodatnich liczb, których suma nie przekracza 1, wówczas $\sum_{i=1}^{n}-p_{i} \log p_{i} \leq \sum_{i=1}^{n}-p_{i} \log q_{i}$ (por.
Jagłom i Jagłom, 1963: 168). 
dane, temu zaś, który nie ma, i to, co ma, będzie odebrane”. W tym wypadku podział dziesięciu min między dziesięciu sług był podziałem równym, a nie według zdolności. „Przypowieść o mierze” w Ewangelii według św. Marka (4: 24-25) kończy się zdaniem: „Bo kto ma, temu będzie dane; a kto nie ma, pozbawią go i tego, co ma.”. W tym ostatnim wypadku w ogóle nie było mowy o podziale dóbr i o ich pomnażaniu.

Nierówności ekonomiczne nieustannie rosną. Najbogatsi powiększają majątki, podczas gdy setki milionów ludzi żyją w skrajnym ubóstwie. Z okazji tegorocznego Światowego Forum Ekonomicznego w Davos organizacja Oxfam², jak co roku, opublikowała raport o globalnych nierównościach. W raporcie podano, że w 2019 roku 2153 najbogatszych $(0,00002833$ proc. ludności Ziemi) zgromadziło w swoich rękach więcej majątku niż 4,6 mld ludzi (stanowiących 60 proc. mieszkańców Ziemi). Szokujące informacje można mnożyć. Już teraz jeden procent najbogatszych ma więcej niż cała reszta ludzkości, a 26 najbogatszych osób na świecie - tyle, co biedniejsza połowa populacji. $\mathrm{W}$ roku poprzednim były to 43 osoby, a dwa lata temu -61 . Od kryzysu w 2008 roku liczba miliarderów prawie się podwoiła. Jednocześnie portal „Bloomberg” poinformował, że 20 najbogatszych ludzi na świecie podwoiło majątki z 672 mld do 1397 mld dolarów. W ostatniej edycji World Inequality Report przygotowanej przez The World Inequality Lab ujawniono, że 27\% całego globalnego wzrostu dochodu między latami 1980 a 2016 zostało uzyskane przez 1\% najbogatszych ludzi, a w ostatnim roku było to już $82 \%$, natomiast połowa najbiedniejszych mieszkańców nie odczuła tego wzrostu w ogóle.

Nierówności ekonomiczne dotyczą nie tylko zgromadzonego majątku, ale również dochodów z pracy i życia w ubóstwie. W okresie między latami 2006 a 2015 wzrost średniego dochodu zwykłych pracowników wynosił $2 \%$ rocznie, podczas gdy majątek miliarderów wzrastał o blisko $13 \%$ rocznie, czyli prawie sześć razy szybciej. W większości krajów w okresie ostatnich trzydziestu lat nastąpił wzrost nierówności dochodów. Dotyczy to też krajów o najliczniejszych populacjach, takich jak Chiny czy Indie. Jednak w krajach Ameryki Łacińskiej w latach dziewięćdziesiątych zaobserwowano najpierw bardzo szybki wzrost nierówności dochodów, a następnie wolny ich spadek w ostatnich piętnastu latach. Od 2008 roku w niektórych krajach, takich jak np. Chiny, również obserwuje się wolny spadek nierówności dochodów. W latach 1990-2010 liczba ludzi żyjących w skrajnym ubóstwie (tj. za mniej niż 1,90 dolara dziennie) podwoiła się i nadal rośnie.

Problem narastających nierówności ekonomicznych jest zjawiskiem szeroko dyskutowanym w mediach i w fachowej literaturze ekonomicznej. Proponowane są licz-

2 Międzynarodowa organizacja humanitarna Oxfam International powstała w $1995 \mathrm{r}$. w wyniku połączenia się kilku organizacji pozarządowych walczących ze światowym ubóstwem i nierównościami. Nazwę zaczerpnęła z Oxford Committee for Famine Relief. Corocznie publikuje raport o nierównościach ekonomicznych i społecznych na świecie. 
ne rozwiązania. Otwarte jest pytanie, czy i jak można byłoby temu przeciwdziałać (por. Atkinson 2015).

\section{Alokacja zasobów w NaUce}

Ponad pięćdziesiąt lat temu Robert K. Merton, wybitny amerykański socjolog, opublikował w „Science” (1968) artykuł, w którym wykazywał, że bardziej znani uczeni otrzymują większe uznanie za swoje osiągnięcia niż mniej znani za podobną pracę. Większe uznanie nie ogranicza się tylko do lepszej reputacji, lecz przekłada się na dostęp do wielu możliwości i dóbr: łatwości publikowania, większych funduszy na badania, lepszych doktorantów, redukcji obciążeń dydaktycznych, dogodniejszych warunków pracy i wielu innych możliwości. Można to określić zasadą skumulowanej przewagi. Merton nazwał ją efektem św. Mateusza, zgodnie z przytoczoną z Biblii „Przypowieścią o talentach”.

Merton analizował psychospołeczne mechanizmy alokacji nagród dla naukowców za ich wkład do nauki. Podstawą tych analiz były wywiady z laureatami Nagrody Nobla, które przeprowadziła jego żona, Harrieta Zuckerman, a także inne dokumenty, w tym wcześniejsze publikacje na temat systemu nagradzania w nauce. Pełniejszą analizę zasady skumulowanej przewagi opublikował Merton dwadzieścia lat później (1988).

Skrajną sytuacją, ale wcale nie taką rzadką, jest przypisywanie uznanemu uczonemu odkrycia dokonanego przez innego uczonego. Na przykład modelem dysku Poincare (lub modelem dysku konformalnego) nazywa się model wprowadzony przez Eugenio Beltrami w 1868 roku, gdy Henri Poincare miał zaledwie 14 lat.

Znacznie częstsze, a nawet dość powszechne, jest przypisywanie uznanemu uczonemu odkrycia dokonanego prawie w całości przez jego współpracownika (nawet doktoranta). Przypisywanie odkrycia uznanemu uczonemu może mieć charakter absolutny, gdy w całości jest ono przypisane temu uczonemu, lub względny, gdy wyżej oceniany jest udział w odkryciu uczonego o ustalonej renomie. Przyznawali to m.in. cytowani przez Mertona (1968) laureaci Nagrody Nobla, którzy wyrażali niezadowolenie lub nawet frustrację z tego powodu, że ich młodszy współpracownik nie został wystarczająco doceniony.

Jedna z hipotez wyjaśniających zasadę skumulowanej przewagi zakłada, że wybitni uczeni są szczególnie uzdolnieni i skłonni do bardzo intensywnej pracy od wczesnych lat, a na drodze edukacyjnej spotykają ich same sukcesy. Te czynniki powodują występowanie efektu skumulowanej przewagi w późniejszym okresie. Badania wy- 
kazują jednak, że - z wyjątkiem pewnych dziedzin - hipoteza ta nie potwierdza się (por. Wagner, 2014: 60).

Jednym z przejawów efektu św. Mateusza jest znacznie większa łatwość publikowania przez uczonych o ustalonej renomie. Redaktorzy czasopism minimalizują wysiłek wkładany w selekcję dostarczanych manuskryptów i chętniej akceptują te, które otrzymują od bardziej znanych autorów, chociaż ich jakość często nie jest wyższa (a bywa również niższa) niż jakość tekstów dostarczanych przez mniej znanych autorów. Znane są eksperymenty wykazujące, że takie same, a nawet te same, manuskrypty są akceptowane, gdy pochodzą od znanych uczonych, a nie są akceptowane, gdy ich autorami są mniej znani naukowcy. Ponadto percepcja obu typów tekstów przez czytelników jest wyraźnie różna.

Czołowe ośrodki akademicko-naukowe (w Stanach Zjednoczonych np. Harvard University, Massachusetts Institute of Technology, Cambridge University, Chicago University) zatrudniają częściej uczonych o uznanej renomie. Stwarzają im lepsze warunki pracy, zapewniają większe fundusze na badania i przedstawiają im do współpracy bardziej obiecujących doktorantów. W ten sposób realizowany jest i potęgowany efekt św. Mateusza.

Izabela Wagner opublikowała w 2014 roku artykuł, w którym przeanalizowała zmiany modelu karier naukowych w Polsce w poprzednich latach. Stwierdziła, że państwo zaczęło ograniczać swoją odpowiedzialność za utrzymanie instytucji i kadr naukowych (np. redukując finansowanie działalności statutowej) i przerzucać na uczonych odpowiedzialność za zdobywanie funduszy - w formie grantów uzyskiwanych w drodze konkursów - na realizację prac naukowych, a także na finansowanie własnego zatrudnienia. Ponadto przy ocenach indywidualnych związanych z zatrudnieniem oraz z przyznawaniem funduszy na badania zaczęto zastępować system oceny jakościowej (tzw. peer review) systemem ilościowym opartym na liczbie publikacji i liczbie uzyskanych punktów za ich cytowania. Promowany przez władze model zbudowany na zasadach konkurencji i indywidualnym postrzeganiu dorobku jest niekorzystny zarówno dla indywidualnej kariery naukowej (niepewność dotycząca własnego zatrudnienia i możliwości prowadzenia pracy naukowej), jak i dla tworzenia zespołów naukowych w celu realizacji ważnych i długofalowych zadań badawczych. System ten „sprawia, iż uwaga młodych naukowców jest skoncentrowana nie na problemach merytorycznych czy naukowych, czy na realizacji palących wyzwań wymagających rozwiązań, ale na utrzymaniu się w wysoko konkurencyjnym świecie nauki, zapewnieniu sobie godziwej pensji i znalezieniu środków na realizację badań" (Wagner, 2014: 44).

Ambitnym celem „Konstytucji dla Nauki”, przyjętej w 2018 roku, jest stworzenie jak najlepszych warunków do rozwoju polskiej nauki, a także dla kształcenia kadr 
przyszłości. Jest ona pierwszą od lat kompleksową propozycją zmiany podejścia do badań naukowych, nauczania studentów i zarządzania uczelnią. „Konstytucja dla Nauki" jest obecnie na etapie wdrażania. Dopiero więc po pewnym czasie możliwe będzie ocenienie, jakie konsekwencje i efekty przyniosła. Zwrócę uwagę tylko na jedno zagadnienie. Zgodnie z założeniami system ocen indywidualnych związanych z zatrudnieniem i przyznawaniem grantów nie wymaga obecnie uzyskiwania punktów za opublikowanie bardzo wielu artykułów w czasopismach naukowych, a jedynie w kilku wysoko punktowanych pismach, najlepiej zagranicznych (tj. będących w obiegu światowym). Jednak system oceny punktowej indywidualnych pracowników naukowych, a także instytucji naukowych, zniechęca do tworzenia zespołów naukowych w ramach własnej instytucji, a preferuje kooperację z osobami z innych instytucji, najlepiej zagranicznych. Punkty za publikacje dzielone są między współautorów z tej samej instytucji, a przypisywane są w całości za współautorstwo z osobami z innych placówek. Dotyczy to zarówno ocen indywidualnych pracowników, jak i całych instytucji.

Uczeni, nawet ci, którzy korzystają z efektu św. Mateusza, uważają, że narusza on normy, które powinny obowiązywać w nauce, i uznają ten efekt za patologię. Jednak nadal mamy z nim do czynienia w nauce. Są jednak i tacy, którzy go bronią i uważają go za właściwy dla funkcjonowania nauki (por. Strevens, 2006).

Na zakończenie warto wspomnieć o tzw. efekcie Matyldy. Termin ten wprowadziła Margaret W. Rossiter w 1993 roku na wzór efektu św. Mateusza. Ma on określać zjawisko dyskryminacji ze względu na płeć w świecie nauki, tj. niedostateczną reprezentację kobiet i ich osiągnięć w środowiskach naukowych. Rossiter nazwała to efektem Matyldy na cześć Matyldy Joslyn Gage - amerykańskiej feministki i sufrażystki, która pod koniec XIX wieku była jedną z pionierek w walce o równe prawa dla kobiet, a także zwróciła uwagę na niedocenianie ich osiągnięć naukowych. W swoim artykule Rossiter (1993) rozważała przede wszystkim fakt, że Komitet Noblowski bardzo rzadko docenia wkład kobiet w rozwój nauki, chociaż bywa on nawet wyższy do wkładu mężczyzn, którym w tych samych dziedzinach przyznano tę nagrodę. Wyjątek stanowiła Maria Skłodowska-Curie, która otrzymała dwie takie nagrody. (Na marginesie: w ciągu 120 lat przyznawania tej nagrody otrzymało ją 47 kobiet i 817 mężczyzn. Wprawdzie można wskazać historyczne wyjaśnienia tych dysproporcji, ale nadal ta tendencja się utrzymuje.) Słyszałem o pewnych pomysłach przeciwdziałania efektowi Matyldy. Polegają one na wymuszonej równości, tj. na stosowaniu parytetu płci autorów przy polecaniu lektur studentom. Wymuszona równość nie jest właściwą metodą postępowania, gdyż kryterium stosowanym w nauce powinna być jakość pracy naukowej, a nie płeć autora. 


\section{Bibliografia}

Abramson, N. (1969). Teoria informacji i kodowania. Warszawa: Państwowe Wydawnictwo Naukowe. Atkinson, A.B. (2015). Inequality. What Can Be Done? Cambridge: Harvard University Press.

Ewangelia według św. Łukasza. (2003). Biblia Tysiąclecia. Poznań: Wydawnictwo Pallotinum.

Ewangelia według św. Mateusza. (2003). Biblia Tysiąclecia. Poznań: Wydawnictwo Pallotinum.

Ewangelia według św. Marka. (2003). Biblia Tysiaclecia. Poznań: Wydawnictwo Pallotinum.

Gluzicka, A. (2017). Wybrane miary oceny stopnia dywersyfikacji portfeli inwestycyjnych. Studia Ekonomiczne, 340, 40-56.

Jagłom, A. M., Jagłom, I. M. (1963). Prawdopodobieństwo i informacja. Warszawa: Książka i Wiedza. Markowitz, H. (1952). Portfolio selection. Journal of Finance, 7, 77-91.

Merton, R.K. (1968). The Matthew effect in science. Science, 159, 56-63.

Merton, R.K. (1988). The Matthew effect in science, II: Cumulative advantage and the symbolism of intellectual property. Isis, 79, 607-623.

Philippatos, G.C., Wilson, C.J. (1972). Entropy, market risk, and the selection of efficient portfolios. Applied Economics, 4, 209-220.

Rossiter, M.W. (1993). The Matthew Matilda Effect in Science Social Studies of Science, Vol. 23, 325-341.

Strevens, M. 2006. The role of the Matthew effect in science. Studies in History and Philosophy of Science, 37, 159-170.

Tyszka, T. (2010). Decyzje. Perspektywa psychologiczna i ekonomiczna. Warszawa: Wydawnictwo Naukowe SCHOLAR.

Wagner, I. (2014). Kariera naukowa w Polsce. Czy obecny model sprzyja wyłanianiu i awansowaniu „najlepszych” naukowców? Przegląd Socjologiczny, 63(3), 39-65.

Zhou, R., Cai, R., Tong, G. (2013). Applications of Entropy in Finance: A Review. Entropy: 15, 4909-4931. 